\title{
АНАЛИЗ КАРТИНЫ КРОВИ ПРИ МАСТОПАТИИ И СОПУТСТВУЮЩЕЙ ПАТОЛОГИИ У КОШЕК
}

\author{
V.V. Chekrysheva
}

\section{BLOOD ANALISIS UNDER MASTOPATHIES AND RELATED PATHOLOGIES IN CATS}

Чекрышева В.В. - канд. ветеринар. наук, доц. каф. акушерства, хирургии и физиологии домашних животных Донского государственного аграрного университета, Ростовская обл., Октябрьский р-н, пос. Персиановский.

E-mail: veterinar1987@mail.ru

В последнее время ветеринарные врачи довольно часто сталкиваются с патологией молочной железы у плотоядных. Особенно часто различные патологии молочной железы регистрируются у кошек. Ввиду особенностей половой цикличности владельцы вынуждены прибегать к гормональной регулящии половой охоты у кошек. Одной из наиболее распространенных проблем является мастопатия. Как известно, мастопатия у кошек диагностируется при избыточном делении видоизмененных клеток в тканях молочных желез. Заболевание оказывает существенное влияние на общее состояние животного и увеличивает риск развития воспалительных и онкологических процессов. Многие авторы относят данное заболевание к предраку. Однако истинные причины и патогенез заболевания до настоящего времени остаются недостаточно изучены. Одновременно с этим 8 структуре заболеваний репродуктивных органов поражения матки занимают одно из лидирующих мест, а среди них преобладают эндометриты. Все более возрастающая актуальность проблемы эндометритов собак связана, наряду с увеличением числа больных животных и высокой летальностью при этой патологии, со значительными экономическими затратами на лечение. Изучаемые вопросы актуальны для плотоядных, которые активно используются в племенном разведении. Содержание животных в квартирах, отсутствие необходимого моциона, вынужденный контроль половых ииклов и беременности серь-
Chekrysheva V.V. - Cand. Veterinary Sci., Assoc. Prof., Chair of Obstetrics, Surgery and Physiology of Pets, Don State Agrarian University, Rostov Region, Oktyabrsky District, S. Persianovsky.

E-mail: veterinar1987@mail.ru

езно влияют на гинекологическое состояние животного. В связи с этим ранняя диагностика мастопатии и сопутствующей патологии позволяет своевременно вмешаться в патологический процесс и не допустить развития онкологического заболевания, а также выбраковки животного. В результате наших исследований установлено, что у кошек с диагнозом "мастопатия" чаще всего в качестве conymствующей патологии наблюдалась акушерскогинекологическая. Самой распространенной акушерской патологией является послеродовый эндометрит. Послеродовый эндометрит и мастопатия находят отражение в общем анализе крови в виде бактериального воспаления, которое проявляется в повышенном уровне лейкоцитов и СОЭ, а также уровне сегментоядерных нейтрофилов. Биохимические показатели находятся в пределах допустимых значений при мастопатии и послеродовом эндометрите.

Ключевые слова: молочная железа, мастопатия, дисгормональная дисплазия молочной железы кошки, патология, акушерская патология, сопутствующая патология, мелкие домашние животные.

Recently, veterinarians quite often encounter the pathology of the mammary gland in carnivores. Especially often, various pathologies of mammary gland are recorded in cats. Due to the peculiarities of sexual cycles, the owners are forced to resort to hormonal regulation of sexual hunting in cats. One of the most common problems is mastopathy. 
Mastopathy in cats is known to be diagnosed with excessive division of altered cells in the tissues of mammary glands. The disease has a significant effect on general condition of the animal and increases the risk of development of inflammatory and oncological processes. However, true causes and pathogenesis of the disease nowadays remain poorly understood. In this regard, early diagnosis of mastopathy allows one to timely intervene in pathological process and prevent the development of cancer. Along with it in the structure of diseases of reproductive organs of damage of the uterus occupy one of leading places, and among them endometritises prevail. More and more increasing relevance of the problem of endometritises in dogs is connected, along with the increase in the number of sick animals and high lethality at this pathology, with considerable economic costs of the treatment. The questions studied are actual for carnivorous which it is actively used in pedigree breeding. Keeping the animals in apartments, the lack of necessary physical exercise, compelled control of sexual cycles and pregnancy seriously influences gynecologic condition of an animal. In this regard early diagnostics of mastopathy and accompanying pathology allows to interfere in due time with pathological process and not to allow development of oncological disease, and also not to allow rejection of an animal. As a result of our studies, it was found out that in cats diagnosed with mastopathy, obstetric and gynecological was most often observed as a concomitant pathology. The most common obstetric pathology is postpartum endometritis. Postnatal endometritis and mastopathy find reflection in general blood analysis in the form of bacterial inflammation which is revealed in increased level of leukocytes and ESR, and also the level of segmented nuclear neutrophils. Biochemical indicators are in the limits of admissible values under mastopathy land postnatal endometritis.

Keywords: mammary gland, mastopathy, dishormonal dysplasia of cat's mammary gland, pathology, obstetric pathology, concomitant pathology, animals, small pets.

Введение. Онкологические заболевания в настоящее время являются одной из причин ключевых вызовов в ветеринарной медицине $[1,2]$. В основе опухолевого роста лежит без- граничное неконтролируемое организмом размножение клеток, что приводит к нарушению функций и разрушению тканей жизненно важных органов и в итоге к смерти организма. В последние годы обращает на себя внимание увеличение числа опухолевых заболеваний у мелких домашних животных, которые достигают $25 \%$ от общей патологии [3]. Одной из наиболее актуальных и сложных проблем в ветеринарии является ранняя диагностика патологии молочной железы $[4,5]$. Своевременная ранняя диагностика является единственным способом борьбы с раком молочной железы как у человека, так и у животных.

Цель исследований. Анализ изменений проб крови по морфологическим и биохимическим показателям у кошек с диагнозом «мастопатия» и сопутствующих патологий.

Задачи: у исследуемых животных изучить частоту возникновения сопутствующих патологий по системам органов; провести общий клинический анализ крови; изучить биохимические показатели крови.

Материалы и методы исследований. Исследования выполнены на базе станции по борьбе с болезнями животных города Ростована-Дону, а также на кафредре акушерства, хирургии и ффизиологии домашних животных ФГБОУ ВО «Донской государственный аграрный университет». Исследованию подверглись кошки, поступающие в ветеринарные лечебницы.

Для постановки диагноза «мастопатия» у кошек проводили общий клинический осмотр, а также специальное исследование половой системы у самок. Клинико-акушерское исследование проводили в следующей последовательности: общее исследование, исследование органов репродуктивной системы, гематологический анализ.

Общее исследование складывалось из определения температуры тела, частоты пульса и дыхательных движений, состояния волосяного покрова, слизистых оболочек, поверхностных лимфоузлов, упитанности, положения тела в пространстве.

Исследование по системам проводили по общепринятой методике. Половую систему исследовали в следующей последовательности: осмотр наружных половых органов, вагиналь- 
ное исследование, пальпация матки через брюшную стенку. При осмотре наружных половых органов обращали внимание на состояние вульвы, количество, периодичность и характер выделений через половую щель. Пальпацией матки определяли болезненность, размер и напряжение ее рогов, наличие флюктуации. При вагинальном исследовании учитывали состояние слизистой оболочки влагалища.

Брали пробы крови из подкожной вены передней конечности для гематологического исследования у кошек с подозрением на мастопатию. Общий анализ крови включал определение количества эритроцитов, лейкоцитов, гемоглобина, выведение лейкоцитарной формулы. Ис- следование биохимических показателей крови, таких как общий белок, общий и прямой билирубин, креатинин, мочевина, АсАТ, АлАТ, аамилаза, щелочная фосфратаза, проводили на анализаторе. Исследованию подверглись 50 животных с признаками мастопатии. В опытные группы включены беспородные кошки в возрасте 5-8 лет. Все животные не были стерилизованы. Помимо исследования основного заболевания проводили анализ сопутствующих патологий у исследуемых животных.

Результаты исследований и их обсуждение. На первом этапе исследований произвели анализ частоты сопутствующих патологий у исследуемых кошек.

Таблица 1

Наличие сопутствующей патологии у исследуемых животных

\begin{tabular}{|l|c|c|}
\hline \multicolumn{1}{|c|}{ Нозологическая единица } & \multicolumn{2}{c|}{ Количество животных } \\
\cline { 2 - 3 } & голов & $\%$ \\
\hline Болезни сердечно-сосудистой системы & 1 & 2 \\
\hline Болезни органов дыхания & 2 & 4 \\
\hline Болезни органов пищеварения & 6 & 12 \\
\hline Болезни печени & 0 & 0 \\
\hline Болезни почек и мочевыводящих путей & 11 & 22 \\
\hline Болезни нервной и эндокринной систем & 0 & 0 \\
\hline Болезни системы крови & 0 & 0 \\
\hline Акушерско-гинекологическая патология & 29 & 58 \\
\hline Хирургические болезни и вмешательства & 1 & 2 \\
\hline Всего & 50 & 100 \\
\hline
\end{tabular}

Из данных таблицы 1 можно сделать вывод, что у кошек с диагнозом «мастопатия» чаще всего в качестве сопутствующей наблюдалась акушерско-гинекологическая патология (58 \%), болезни почек и мочевыводящих путей отмечались в $22 \%$ случаев, болезни органов пищеварения в $12 \%$ случаев от общего числа исследуемых животных, болезни органов дыхания 4 \%. Среди акушерско-гинекологических патологий наибольшее распространение имели послеродовой эндометрит (60\%), а также задержание последа $(24,1 \%)$. У исследуемых животных из патологий почек и мочевыводящих путей наи- более часто встречался цистит, лишь у одного животного отмечалась мочекаменная болезнь. Среди болезней органов пищеварения отмечались патология поджелудочной железы и гастрит. Среди патологии органов дыхания регистрировался ринит как следствие инфекционного ринотрахеита. Таким образом, акушерскогинекологическая патология при мастопатии встречается наиболее часто у кошек, больных мастопатией.

Результаты исследования морфологических показателей крови и СОЭ у подопытных кошек отражены в таблице 2. 
Общий клинический анализ крови исследуемых кошек

\begin{tabular}{|c|c|c|}
\hline Показатель & Референтные значения & Количественный показатель \\
\hline Гемоглобин, г/л & $80-150$ & $112,3+/-8,86$ \\
\hline Эритроциты, млн/мм³ & $6,6-9,4$ & $8,01+/-0,65$ \\
\hline Лейкоциты, тыс/мм³ & $10,0-20,0$ & $26,2+/-3,33$ \\
\hline СОЭ, мm/4 & $0-13$ & $25,73+/-2,55$ \\
\hline Базофиилы & $0-1$ & $0,33+/-0,4$ \\
\hline Эозинофилы & $2-8$ & $7,1+/-2,3$ \\
\hline $\begin{array}{l}\text { Нейтрофилы: } \\
\text { юные }\end{array}$ & $0-1$ & $0,2+/-0,32$ \\
\hline палочкоядерные & $3-9$ & $7,9+/-3,3$ \\
\hline сегментоядерные & $40-45$ & $52,6+/-2,96$ \\
\hline Моноциты & $1-5$ & $1,2+/-0,65$ \\
\hline Лимсфоциты & $36-51$ & $45+/-3,46$ \\
\hline
\end{tabular}

Из данных таблицы 2 видно, что у исследованных животных отмечалась выраженная воспалительная реакция, которая проявляется в повышенном уровне лейкоцитов и СОЭ. Так, уровень лейкоцитов составлял 26,2+/-3,33 тыс/мм³ же отмечалось повышение содержания сегментоядерных нейтросилов до 52,6+/-2,96, что характерно для воспалительного процесса бактериальной этиологии. Однако такие изменения картины крови могут происходить и в результате течения сопутствующих заболеваний половой системы, а именно - эндометритов и задержания последа.

Из данных таблицы 3 можно сделать вывод, что мастопатия у кошек не находит отражения в результатах биохимического анализа крови. Все биохимические показатели находятся в пределах допустимых норм.

\section{Биохимические показатели крови кошек с диагнозом «мастопатия»}

Таблица 3

\begin{tabular}{|l|c|c|}
\hline \multicolumn{1}{|c|}{ Показатель } & $\begin{array}{c}\text { Ресрерентные } \\
\text { значения }\end{array}$ & Количественный показатель \\
\hline Общий белок, г/л & $40-73$ & $58,8+/-6,8$ \\
\hline $\begin{array}{l}\text { Билирубин, Ммоль/л: } \\
\text { общий }\end{array}$ & $3-13,5$ & $10,04+/-1,56$ \\
\hline прямой & $0-5,5$ & $1,22+/-0,58$ \\
\hline Креатинин, Мкмоль/л & $26-120$ & $75,1+/-27,8$ \\
\hline Мочевина, Ммоль/л & $3,5-9,2$ & $6,9+/-1,1$ \\
\hline АсАТ, ЕД/л & $11-42$ & $31+/-4,8$ \\
\hline АлАТ, ЕД/л & $9-52$ & $32,5+/-11,9$ \\
\hline а-амилаза, ЕД/л & $685-1800$ & $955,4+/-90,6$ \\
\hline Щелочная фоссратаза, ЕД/л & $18-75$ & $46,3+/-9,2$ \\
\hline
\end{tabular}

\section{Выводы}

1. При мастопатии у кошек чаще всего возникает сопутствующая патология в виде аку- шерско-гинекологических болезней (58 \%), таких как задержание последа $(24,1 \%)$ и эндометрит (60\%). Патология почек и мочевыводящих путей встречается в 22 \% случаев. Наиболее час- 
то возникает цистит. В 12 \% случаев встречается патология пищеварительной системы, а именно - панкреатиты и гастрит.

2. При мастопатии у кошек отмечается выраженная воспалительная реакция: повышенный уровень лейкоцитов и СОЭ, а также сегментоядерных нейтрофилов, что свидетельствует о выраженном бактериальном воспалительном процессе.

3. Мастопатия у кошек, как самостоятельная патология, не находит отражения в биохимическом анализе крови.

\section{Литература}

1. Дюльгер Г.П., Седлецкая Е.С. Акушерство, гинекология и биотехника размножения кошек: учеб. пособие. - 2-е изд., испр. и доп. - СПб.: Лань, 2018. - 168 с.

2. Жуков В.М. Органопатология молочной железы у кошек и собак// Вестник Алтайского государственного аграрного университета 2018. - № 7. - С. 95-98.

3. Чекрышева В.В. Клиническая характеристика доброкачественной дисплазии молочной железы (ДДМЖ) у кошек // Фундаментальные и прикладные науки сегодня: мат-лы $\mathrm{V}$ междунар. науч.-практ. конф. М., 2015. - C. 9-12.

4. Немкова О.С., Донкова Н.В. Клиникоморфологическая диагностика новообразований молочной железы у кошек // Вестник КрасГАУ. - 2012. - № 1. - С. 143-146.

5. Клинико-гематологическая характеристика мастопатии у мясоядных и картина крови при данной патологии / В.В. Чекрышева,
Л.Г. Войтенко, Т.Н. Сочинская [и др.] // Актуальные проблемы и методические подходы к диагностике, лечению и профилактике болезней животных: мат-лы междунар. науч.-практ. конф. - 2016. - С. 87-92.

\section{Literatura}

1. Djul'ger G.P., Sedleckaja E.S. Akusherstvo, ginekologija i biotehnika razmnozhenija koshek: ucheb. posobie. - 2-e izd., ispr. i dop. - SPb.: Lan', 2018. - $168 \mathrm{~s}$.

2. Zhukov V.M. Organopatologija molochnoj zhelezy u koshek i sobak// Vestnik Altajskogo gosudarstvennogo agrarnogo universiteta 2018. - № 7. - S. 95-98.

3. Chekrysheva V.V. Klinicheskaja harakteristika dobrokachestvennoj displazii molochnoj zhelezy (DDMZh) u koshek // Fundamental'nye i prikladnye nauki segodnja: mat-ly $\mathrm{V}$ mezhdunar. nauch.-prakt. konf. - M., 2015. - S. 9-12.

4. Nemkova O.S., Donkova N.V. Klinikomorfologicheskaja diagnostika novoobrazovanij molochnoj zhelezy u koshek // Vestnik KrasGAU. - 2012. - № 1. - S. 143146.

5. Kliniko-gematologicheskaja harakteristika mastopatii u mjasojadnyh i kartina krovi pri dannoj patologii / V.V. Chekrysheva, L.G. Vojtenko, T.N. Sochinskaja [i dr.] // Aktual'nye problemy i metodicheskie podhody $k$ diagnostike, lecheniju i profilaktike boleznej zhivotnyh: mat-ly mezhdunar. nauch.-prakt. konf. - 2016. - S. 87-92. 